\title{
9th Bi-annual International Conference on Naturalistic Decision Making (NDM9)
}

\author{
ndming \\ BCS London \\ 23 - 26 June 2009
}

Editors:

B.L. William Wong

Neville A. Stanton 


\section{Abstract}

Jointly organised with the BCS Interaction Specialist Group

Naturalistic Decision Making (NDM) encapsulates the problems and challenges associated with making decisions in demanding situations. These decisions are often dependent on, or supported by, computing technology. The conference focuses on contemporary research on NDM where interaction with computing technology is an essential feature.

\section{Main sponsors:}

US Army USAITC-A

UK MoD's Human Factors Integration Defence Technology Centre (HFI-DTC)

Ashgate Publishing Ltd

\section{Other sponsors:}

BCS Interaction SG

Southampton University

Middlesex University 


\section{Editors}

This conference was edited by:

B.L. William Wong - Interaction Design Center, School of Engineering and Information Sciences, Middlesex University

Neville A. Stanton - Transportation Research Group, School of Civil Engineering and the Environment, University of Southampton 


\section{Conference Committee}

Conference committee members are listed below.

\section{Co-Chairs}

Neville Stanton (University of Southampton)

William Wong (Middlesex University)

\section{Scientific Programme Chairs}

Neville Stanton (University of Southampton)

William Wong (Middlesex University)

Michael Strub (US ARL / DSTL)

Nick Sevdalis (Imperial College)

Julie Gore (University of Surrey)

\section{Fundraising}

Michael Strub (US ARL / DSTL)

\section{Student Volunteers}

Nick Sevdalis (Imperial College)

\section{Doctoral Consortium}

Julie Gore (University of Surrey)

\section{Website}

Neesha Kodagoda (Middlesex University) 


\section{Social Programme}

Gaby Mancero (Middlesex University)

Laura Raffety (Brunel University)

\section{Conference Secretariat}

Rachel Browning (BCS) 


\section{Papers:}

\section{Keynotes}

Chris Baber Wearable Technology for Crime Scene Examination: distributed cognition and naturalistic decision making http://dx.doi.org/10.14236/ewic/NDM2009.1

Nigel Shadbolt Towards Network-Enabled Cognition http://dx.doi.org/10.14236/ewic/NDM2009.2

\section{Paper Presentations}

Markus Vanharanta Social Structure in Naturalistic Decision Making http://dx.doi.org/10.14236/ewic/NDM2009.3

Jan Maarten Schraagen, Josine van de Ven, Paul Barach and Meike Smit Teams and Cardiac Surgery $\quad$ http://dx.doi.org/10.14236/ewic/NDM2009.4

James Shanteau, Alleene M. Pingenot and James D. F. Pingenot Evaluation of Medication System Interface $\quad$ http://dx.doi.org/10.14236/ewic/NDM2009.5

Antonio Sanfilippo, Andrew J. Cowell, Liz Malone, Roderick Riensche, Jim Thomas, Stephen Unwin, Paul Whitney and Pak Chung Wong Technosocial Predictive Analytics in Support of Naturalistic Decision Making http://dx.doi.org/10.14236/ewic/NDM2009.6

Lelyn D. Saner and Cleotilde Gonzalez Naturalistic Decision Framing in Computer Mediated Scientific Exploration http://dx.doi.org/10.14236/ewic/NDM2009.7

Robert Patterson, Lisa Fournier, Byron Pierce, Marc Winterbottom and Lisa Tripp Modeling the Dynamics of Recognition-Primed Decision Making http://dx.doi.org/10.14236/ewic/NDM2009.8

Shane T. Mueller, Gary Klein and Christopher Burns Experiencing the Tool without Experiencing the Pain: Concepts for an Experiential User Guide http://dx.doi.org/10.14236/ewic/NDM2009.9

Kathleen L. Mosier and Ute M. Fischer Does Affect Matter in Naturalistic Decision Making? http://dx.doi.org/10.14236/ewic/NDM2009.10

Ben W. Morrison, Mark W. Wiggins, Nigel W. Bond and Michael D. Tyler Examining cue recognition across expertise using a computer-based task http://dx.doi.org/10.14236/ewic/NDM2009.11 
Gary Klein and Robert Hoffman Causal Reasoning: Initial Report of a Naturalistic Study of Causal Inferences http://dx.doi.org/10.14236/ewic/NDM2009.12

Tony Kendall and Susan G. Hutchins Use of a Team Collaboration Model to Identify Candidate Knowledge Management and Collaboration Technologies http://dx.doi.org/10.14236/ewic/NDM2009.13

Robert. R. Hoffman and Thomas C. Eskridge Varieties of Analogical Reasoning http://dx.doi.org/10.14236/ewic/NDM2009.14

Caroline C. Hayes and Farnaz Akhavi Combining Naturalistic and Mathematical Decision Aids to Support Product Design ～http://dx.doi.org/10.14236/ewic/NDM2009.15

David Dean, Alasdair Vincent, Beejal Mistry, Aleem Hossain and Mink Spaans Representing a Combat ID Analysis Tool within an Agent Based Constructive Simulation http://dx.doi.org/10.14236/ewic/NDM2009.16

\section{Poster Presentations}

Adrian Banks, Julie Gore and Rebecca Smith Decision Making in Selection Interviews http://dx.doi.org/10.14236/ewic/NDM2009.17

Cyril Bossard, Gilles Kermarrec, Romain Bénard, Pierre De Loor and Jacques Tisseau Investigate Naturalistic Decision Making of Football Players to Design Virtual Environment http://dx.doi.org/10.14236/ewic/NDM2009.18

Graham Coull, John Tripp, Michael Davies and Rhona Flin Critical Incident Management by Teleconference: Identifying Non-Technical Skills http://dx.doi.org/10.14236/ewic/NDM2009.19

Donald A. Cox and Beth Veinott Developing Pattern Languages: New Ways of Communicating Naturalistic Insights for System Development and Evaluation http://dx.doi.org/10.14236/ewic/NDM2009.20

Natalie Cropp, Adrian Banks and Lucia Elghali Expert Judgment in Contaminated Land Assessment http://dx.doi.org/10.14236/ewic/NDM2009.21

Bill Davilas and Nicolas Marmaras Analysis of the FX traders' work using the Naturalistic Decision Making framework http://dx.doi.org/10.14236/ewic/NDM2009.22

Corey Fallon and Cynthia Dominguez Build the Picture, Build the Plan: The Role of Control Room Displays in Team Sensemaking http://dx.doi.org/10.14236/ewic/NDM2009.23

Markus A. Feufel and Valerie L. Shalin Electronic medical records and NDM in U.S. emergency departments: A preliminary analysis http://dx.doi.org/10.14236/ewic/NDM2009.24 
Silvia Gilardi, Chiara Guglielmetti, Shawna J. Perry, Gabriella Pravettoni and Robert L. Wears Changing Horses in Midstream: Sudden Changes in Plan in Dynamic Decision-making Problems http://dx.doi.org/10.14236/ewic/NDM2009.25

Timothy P. Hanratty, Xiacong Fan and Robert J. Hammell II Leveraging Visualization to Improve Sensemaking within a Computational RPD Model http://dx.doi.org/10.14236/ewic/NDM2009.26

Ian M. Kinchin Concept mapping of knowledge structures to visualize the nature of expertise in clinical education http://dx.doi.org/10.14236/ewic/NDM2009.27

Daniel Lafond, Jean-François Gagnon, Sébastien Tremblay and Michel Lizotte IMAGE: A ComputerAided Cognition Capability for Understanding Complex Systems http://dx.doi.org/10.14236/ewic/NDM2009.28

Kristina Lauche, Margaret Crichton and Petra Saskia Bayerl Tactical Decision Games: Developing Scenario-Based Training for Decision-Making in Distributed Teams http://dx.doi.org/10.14236/ewic/NDM2009.29

Mei-Hua Lin and Helen Altman Klein Sensemaking During Unfolding Events http://dx.doi.org/10.14236/ewic/NDM2009.30

Jenna L.Marquard and Patricia Flatley Brennan A Misfit Tool: Patients' (Lack of) Use of a Structured Decision Aid http://dx.doi.org/10.14236/ewic/NDM2009.31

Jenna L. Marquard, Stefan Christov, Philip L. Henneman, Lori A. Clarke, Leon J. Osterweil, George S. Avrunin, Donald L. Fisher, Elizabeth A. Henneman, Megan M. Campbell, Tuan A. Pham and Qi Ming Lin Studying Rigorously Defined Health Care Processes Using a Formal Process Modeling Language, Clinical Simulation, Observation, and Eye Tracking http://dx.doi.org/10.14236/ewic/NDM2009.32

Jenna L. Marquard and Patricia Flatley Brennan Using Decision Scenarios to Evaluate Laypeople's Computer-Mediated Medication Information Sharing Choices http://dx.doi.org/10.14236/ewic/NDM2009.33

Claire McAndrew and Julie GoreDay Traders, Computers and the Trading Floor - Interactional Expertise? http://dx.doi.org/10.14236/ewic/NDM2009.34

Claire McAndrew and Teal Triggs Counter Terrorism: Risk Perception and Communication in Naturalistic Environments http://dx.doi.org/10.14236/ewic/NDM2009.35

Patricia L. McDermott, Michael Barnes and Shaun Hutchins Displays and Decisions - The Chicken or the Egg? The Influence of Displays on the Decision Making Process http://dx.doi.org/10.14236/ewic/NDM2009.36

Laura G. Militello, Drew M. Bowers, Thomas R. Boehnlein, Robert B. Olding and Keith Ambrose Visualizations: From complex analyses to actionable findings http://dx.doi.org/10.14236/ewic/NDM2009.37

Kathleen L. Mosier, Paula Rettenmaier, Matthew McDearmid, Stefanie Ng, Jordan Wilson, Stanton Mak 
and Judith Orasanu Effects of Operator State on Pilot/ATC Conflict http://dx.doi.org/10.14236/ewic/NDM2009.38

Anne-Sophie Nyssen and Adélaïde Blavier Verbal Communication as a sign of adaptation in sociotechnical systems: The case of robotic surgery http://dx.doi.org/10.14236/ewic/NDM2009.39

Liliane Pellegrin, Charlotte Gaudin, Nathalie Bonnardel, Gaetan Texier, Jean Baptiste Meynard and Hervé Chaudet Formalizing collaboration in decision-making: a case study in military epidemiological early warning http://dx.doi.org/10.14236/ewic/NDM2009.40

Michael A. Rosen, Stephen M. Fiore and Eduardo Salas Managing Uncertainty in Macrocognition: A Multi-disciplinary Review and Integration $\quad$ http://dx.doi.org/10.14236/ewic/NDM2009.41

Sonia Savelli and Susan Joslyn Visualizing Temperature Forecast Uncertainty for a Non-expert Web Audience http://dx.doi.org/10.14236/ewic/NDM2009.42

Luiz Maurício de Andrade da Silva, Laércio Aparecido Lucas and Maurício Pereira da Costa Analysis of the Decision Making Process of Flight Instructors at the Brazilian Air Force Academy

(AFA) http://dx.doi.org/10.14236/ewic/NDM2009.43

Dorian Soru, Paolo Cottone, Gianmarco Altoè, Valentina Schiavinato and Giuseppe Mantovani Developing a Simulated Environment to Study Naturalistic Decision Making Processes http://dx.doi.org/10.14236/ewic/NDM2009.44

Neville A. Stanton, Guy H. Walker, Daniel P. Jenkins and Paul M. Salmon Constraint-based Naturalistic Decision Making in Mission Planning Teams http://dx.doi.org/10.14236/ewic/NDM2009.45

Lygia Stewart, Cynthia O. Dominguez and Lawrence W. Way Intra-operative Sensemaking by Surgeons: Analysis of Operative Reports for Uncertainty and Irregular Cues http://dx.doi.org/10.14236/ewic/NDM2009.46

Peter Thunholm and Mervyn Cheah Exploiting Computer Technologies for Military Integrated Mission Planning http://dx.doi.org/10.14236/ewic/NDM2009.47

Markus Vanharanta and Mark Stevenson NDM Integrated Organizational Structure and the Growth of Organizations http://dx.doi.org/10.14236/ewic/NDM2009.48

Beth Veinott, Donald Cox and Shane Mueller Social media supporting disaster response: Evaluation of a lightweight collaborative tool http://dx.doi.org/10.14236/ewic/NDM2009.49

Jeff Waters, Ritesh Patel, James Eitelberg and Marion G. Ceruti A Proposed Common DecisionExchange Protocol for Representing, Managing, and Sharing Organizational Decisions http://dx.doi.org/10.14236/ewic/NDM2009.50

Marc Winterbottom, Robert Patterson, Lisa Fournier, Byron Pierce, Logan Williams and Ryan Amann Decision Priming in an Air-to-Ground Attack Decision Scenario http://dx.doi.org/10.14236/ewic/NDM2009.51 
Celestine A. Ntuen Sensemaking and Visualization for Situation Cognition http://dx.doi.org/10.14236/ewic/NDM2009.52

\section{Panels}

Silvia Gilardi, Chiara Guglielmetti, Shawna J. Perry, Gabriella Pravettoni, Stephanie Wilson and Robert L. Wears People, Technology, and Complex Work in Healthcare http://dx.doi.org/10.14236/ewic/NDM2009.53

Richard May, Jörn Kohlhammer and David S. Ebert Enabling Critical Analytic Thinking http://dx.doi.org/10.14236/ewic/NDM2009.54

\section{Doctoral Consortium Presentations}

Harris Shah Abd Hamid, Patrick Waterson and Sue Hignett Situation Awareness to Support Decision-Making among Emergency Care Practitioners http://dx.doi.org/10.14236/ewic/NDM2009.55

Charlotte Gaudin, Nathalie Bonnardel, Liliane Pellegrin and Hervé Chaudet Collective DecisionMaking in Complex Situations: a Dynamic Role in Alert Management http://dx.doi.org/10.14236/ewic/NDM2009.56

Stephen T. Hassard The Variations of Recognition Primed Decision-Making and How it Informs Design Decision-Making ～http://dx.doi.org/10.14236/ewic/NDM2009.57

Neesha Kodagoda, William Wong and Nawaz Kahan Identifying Information Seeking Behaviours of Low and High Literacy Users: Combined Cognitive Task Analysis http://dx.doi.org/10.14236/ewic/NDM2009.58

Dan Lockton, David Harrison and Nevilla A. Stanton Choice Architecture and Design with Intent http://dx.doi.org/10.14236/ewic/NDM2009.59

Garry James Marling and Tim Horberry Operator Decision Making Before Starting and While Doing an Activity/Task: Development and Evaluation of Integrated Front-end Priming and Heuristic Risk Management Tools for Operators http://dx.doi.org/10.14236/ewic/NDM2009.60

Laura A. Rafferty, Neville A. Stanton and Guy H. Walker Fratricide: Defective Decision Making http://dx.doi.org/10.14236/ewic/NDM2009.61

Tom Robinson and Catherine Burns Computer Algebra Systems and Their Effect on Cognitive Load http://dx.doi.org/10.14236/ewic/NDM2009.62

Simone Rozzi, Paola Amaldi and Barry Kirwan Identifying how automation can lose its intended benefit 
Yu Zhao, Sue Hignett and Neil Mansfield Computerised Link Analysis http://dx.doi.org/10.14236/ewic/NDM2009.64 